\title{
Crossability Studies in China Aster [Callistephus chinensis (L.) Nees]
}

\author{
Pratiksha Kumari*, Rajiv Kumar, T. Manjunatha Rao, T. Usha Bharathi, \\ M.V. Dhananjaya and V. Bhargav
}
Division of Floriculture and Medicinal Crops, ICAR-Indian Institute of Horticultural Research, Hesaraghatta Lake Post, Bengaluru 560 089, Karnataka, India

*Corresponding author

\begin{tabular}{|c|c|}
\hline & A B S T R A C T \\
\hline $\begin{array}{l}\text { Ke y w o r d s } \\
\text { Callistephus } \\
\text { chinensis, } \\
\text { China aster }\end{array}$ & \multirow{3}{*}{$\begin{array}{l}\text { Crossability in } 15 \mathrm{~F}_{1} \text { hybrids and } 8 \text { parents ( } 5 \text { lines and } 3 \text { testers) of China aster were } \\
\text { studied using Line } \mathrm{x} \text { Tester mating design. The crossability relationship in different crosses } \\
\text { was determined by days taken for hybrid seed maturity, total number of seeds/cross, seed } \\
\text { weight/cross }(\mathrm{g}) \text { and } 100 \text { seed weight }(\mathrm{g}) \text {. The results revealed that the parent Local Pink } \\
\text { recorded highest number of seeds per flower head }(203.75) \text { and weight of seeds per flower } \\
\text { head }(0.54 \mathrm{~g}) \text {. The number of days taken from pollination to hybrid seed maturity was } \\
\text { ranged from } 31.33 \text { days (Arka Archana } \mathrm{x} \text { Local Pink) to } 39.83 \text { days (Arka Poornima } \mathrm{x} \\
\text { Arka Shashank). The cross Arka Poornima x Local Pink recorded highest total number of } \\
\text { seeds per cross }(111.17) \text { and weight of seeds per cross }(0.29 \mathrm{~g}) \text {. The average } 100 \text { seeds } \\
\text { weight in } \mathrm{F}_{1} \text { hybrids }(0.269 \mathrm{~g}) \text { was higher than that of parents }(0.242 \mathrm{~g}) \text {. All the } 15 \mathrm{~F}_{1} \\
\text { hybrids exhibited heterosis over commercial check cv. Arka Kamini for } 100 \text { seeds weight. }\end{array}$} \\
\hline Article Info & \\
\hline $\begin{array}{l}\text { Accepted: } \\
\text { 20 January } 2018 \\
\text { Available Online: } \\
10 \text { February } 2018\end{array}$ & \\
\hline
\end{tabular}

\section{Introduction}

China aster, family Asteraceae, has single species Chinensis and is native to China (Navalinskien et al., 2005). The plant was introduced in Europe in 1731 by a Jesuit missionary, R P d' Incarville (Bailey, 1942). According to Emsweller (1948), the original form of China aster was single type flower with 2-4 rows of ray florets with red, blue, violet and white colours and numerous yellow disc florets. In China aster, pollen is discharged first after which the stigma unfolds, hence, this is geitonogamous crop (Sheela, 2008). Its sporophytic (2n) chromosome number is reported to be 18
(Kong, 2000). China aster is seed propagated flowering annual crop. Strube (1965) described its floral biology. The flower of China aster is head or capitulum which comprises of outer ray florets (psitillate) and central disc florets (hermaphrodite). The opening of the ray florets is from periphery towards the centre. This pattern of florets opening renders stigma receptivity for a period of several days (Watts, 1980). North (1979) and Watts (1980) grouped China aster under self-pollinated crops, though, Fleming (1937) reported natural crossing (approximately 10\%). Single and semi-double varieties are predominantly cross pollinated, while double flowered varieties are generally 
self pollinated (Strube, 1965 and Janakiram, 1997). Novotna (1989) reported that the number of seeds produced by tubular flowers was higher than number of seeds produced by ligulate flowers in same anthodium. There is variation in the seed setting pattern in genotypes and different crosses. Therefore, the present study was undertaken to study the crossability in $15 \mathrm{~F}_{1}$ hybrids and 8 parents of China aster.

\section{Materials and Methods}

\section{Selection of genotypes}

Five lines namely Arka Kamini, Arka Poornima, Arka Aadya, Arka Archana and Arka Violet Cushion were crossed with three testers namely Arka Shashank, Local Violet, Local Pink to develop $15 \mathrm{~F}_{1}$ hybrids. All the genotypes taken were stabilized and maintained at ICAR-IIHR, Bangalore. A total of 23 treatments ( $15 \mathrm{~F}_{1}$ hybrids, 5 lines and 3 testers) were evaluated in RCBD with three replications. The data recorded were pooled and analysed statistically.

\section{Emasculation and pollination}

The crossing process includes handemasculation followed by hand-pollination. Emasculation was performed at half-opened bud stage by removing all the disc florets with the help of surgical blade and forceps. Emasculated flower buds were covered with butter paper bag. On $3^{\text {rd }}$ day, when stigma receptivity was high, pollen from the tester (male parent) was dusted over the emasculated flower between 11.00 am to 1.00 $\mathrm{pm}$. In order to avoid contamination with foreign pollen, the pollinated buds were covered with perforated butter paper bags and information regarding female and male parents, date of emasculation and pollination were mentioned on the tag attached with pollinated flower.
The crossed seeds were collected between 30 to 40 days when they were sufficiently dry. The mature seeds were collected individually, dried, counted and weighed. Individually selfed seeds from parents were also collected, counted and weighed. The $F_{1}$ hybrid seeds and selfed seeds of parent were stored in sealed aluminium sachets inside cold chamber at $2^{\circ} \mathrm{C}$. The observations were recorded on number of seeds per flower head, weight of seeds per flower head (g), days taken for hybrid seed maturity, total number of seeds per cross, seed weight per cross (g), 100 seed weight (g). For 100 seed weight, estimation of heterosis over mid parent, better parent and commercial check cv. Arka Kamini was done to understand the amount of heterosis for seed weight in $\mathrm{F}_{1}$ hybrids.

\section{Results and Discussion}

Fifteen crosses were made in line $\mathrm{x}$ tester $(5 \mathrm{x}$ 3 ) mating design. The data pertaining to seed parameters are presented in Table 1. Among parents, significant variation was recorded for number of seeds per flower head. The maximum number of seeds per flower head was recorded in Local Pink (203.75), followed by Arka Poornima (194.80) and Arka Archana (175.85), while it was recorded minimum in Arka Violet Cushion (9.95). Among parents, significant differences were recorded for weight of seeds per flower head. The maximum weight of seeds per flower head was recorded in Local Pink (0.54 g), followed by Arka Archana (0.45 g) and Arka Poornima $(0.43 \mathrm{~g})$, while it was recorded minimum in Arka Violet Cushion (0.029).

Seed setting in China aster is mainly attributed on the proportion of disc and ray florets existing in a flower-head, pollinators and variation due to season (Khangjarakpam et al., 2014). In cv. Poornima, low seed yield is due to minimal overlapping of stigma receptivity and pollen viability in tubular disc 
florets (Padmini et al., 2012). Planting during first week of October recorded highest seeds yield in China aster (Yadav, 1983), as seed setting is influenced by planting season also.

Among $F_{1}$ hybrids, significant differences were recorded for days taken for hybrid seed maturity. The earliest hybrid seed maturity was recorded in cross Arka Archana x Local Pink (31.33 days) followed by Arka Archana $x$ Local Violet (31.92 days) and Arka Kamini $\mathrm{x}$ Local Pink (32.33 days), while it was delayed in Arka Poornima x Arka Shashank (39.83 days). Seed harvesting after 40 days of pollination improved seed setting (Khangjarakpam et al., (2014) and 40 days after anthesis in genotypes (Selvakumari et al., 2006) in China aster. Selvakumari et al., (2006) further reported that physiological maturity is pre-requisite for seeds setting in cv. 'Poornima'. Phetpradap (1992) described right stage of harvesting as visibility of feathery pappus.

Among $F_{1}$ hybrids, significant differences were recorded for total number of seeds per cross. The maximum total number of seeds per cross was recorded highest in Arka Poornima x Local Pink (111.17 days) followed by Arka Poornima x Local Violet (103.42 days), Arka Violet Cushion x Local Violet (91.50 days), while it was recorded minimum in Arka Violet Cushion $\mathrm{x}$ Arka Shashank (31.50 days).

Among crosses, significant variation was recorded for seed weight per cross. The maximum weight of seeds per cross was recorded highest in Arka Poornima $x$ Local Pink $(0.29 \mathrm{~g})$ followed by Arka Violet Cushion x Local Violet (0.25 g) and Arka Poornima $\mathrm{x}$ Local Violet $(0.25 \mathrm{~g})$, while it was recorded minimum in Arka Violet Cushion x Arka Shashank (0.092 g). Among $\mathrm{F}_{1}$ hybrids and parents, significant variation was recorded for 100 seed weight. The maximum weight of 100 seed was recorded in
Arka Shashank (0.32 g) followed by Arka Archana x Arka Shashank (0.30 g), Arka Archana x Local Violet (0.29 g), Arka Violet Cushion x Arka Shashank (0.29 g), Arka Violet Cushion x Local Pink (0.29 g), while it was minimum in Arka Kamini (0.21 g), Arka Aadya (0.21) and Local Violet (0.21). The variation in 100 seed weight is mainly due to seed size of an individual genotype which is genetically controlled.

In general, the seed setting in pompon as well as powderpuff type flowers is lower than semi-double forms since long tubular disc florets limit cross pollination. Hand pollination can improve the seed-set in pompon type. The variation in number of seeds per cross is also influenced by the genetic makeup of their parents. Variation in number of seeds among the genotype has also been reported (Sajabapu, 2015). Munikrishnappa (2011) reported maximum seed set in cv. Phule Ganesh White (10.50 $\mathrm{g} /$ plant), while minimum seed set in cv. Kamini (3.75 g/plant) in China aster.

Khangjarakpam et al., (2014) reported seed setting in China aster genotypes and their cross combinations. Maximum 1000 seed weight was recorded in Arka Shashank (2.61 g) followed by Arka Violet Cushion (2.03 g) and Arka Kamini (1.82 g), however, minimum 1000 seed weight was recorded in Arka Poornima (1.66 g).

\section{Estimates of heterosis (\%) for 100 seeds weight}

The data pertaining estimate of heterosis for 100 seeds weight are presented in Table 2 . Heterosis over mid-parent was ranged from 2.40 (Arka Poornima x Arka Shashank) to 23.57 (Arka Archana x Local Violet); heterosis over better parent ranged from 17.95 (Arka Poornima x Arka Shashank) to 17.02 (Arka Kamini x Local Violet). 
Table.1 Seed parameters in $15 \mathrm{~F}_{1}$ hybrids and their parents

\begin{tabular}{|c|c|c|c|c|c|c|}
\hline $\mathrm{F}_{1}$ hybrids/Parents & $\begin{array}{c}\text { Number of } \\
\text { seeds/flower head }\end{array}$ & $\begin{array}{c}\text { Weight of } \\
\text { seeds/flower head }(\mathrm{g})\end{array}$ & $\begin{array}{c}\text { Days taken for } \\
\text { hybrid seed maturity }\end{array}$ & $\begin{array}{l}\text { Total number } \\
\text { of seeds/cross }\end{array}$ & $\begin{array}{l}\text { Seed weight/ } \\
\text { cross }(\mathrm{g})\end{array}$ & $\begin{array}{c}100 \text { seed } \\
\text { weight }(\mathrm{g})\end{array}$ \\
\hline Arka Kamini x Arka Shashank & - & - & 37.17 & 35.58 & 0.097 & 0.27 \\
\hline Arka Kamini x Local Violet & - & - & 34.42 & 67.42 & 0.17 & 0.25 \\
\hline Arka Kamini x Local Pink & - & - & 32.33 & 56.17 & 0.14 & 0.25 \\
\hline Arka Poornima x Arka Shashank & - & - & 39.83 & 52.92 & 0.14 & 0.27 \\
\hline Arka Poornima x Local Violet & - & - & 38.92 & 103.42 & 0.25 & 0.24 \\
\hline Arka Poornima x Local Pink & - & - & 38.33 & 111.17 & 0.29 & 0.26 \\
\hline Arka Aadya x Arka Shashank & - & - & 36.25 & 35.83 & 0.098 & 0.27 \\
\hline Arka Aadya x Local Violet & - & - & 35.08 & 40.67 & 0.10 & 0.25 \\
\hline Arka Aadya x Local Pink & - & - & 35.17 & 51.42 & 0.14 & 0.26 \\
\hline Arka Archana x Arka Shashank & - & - & 36.50 & 63.83 & 0.19 & 0.30 \\
\hline Arka Archana x Local Violet & - & - & 31.92 & 82.92 & 0.24 & 0.29 \\
\hline Arka Archana x Local Pink & - & - & 31.33 & 82.42 & 0.23 & 0.28 \\
\hline $\begin{array}{l}\text { Arka Violet Cushion x Arka } \\
\text { Shashank }\end{array}$ & - & - & 36.92 & 31.50 & 0.092 & 0.29 \\
\hline $\begin{array}{l}\text { Arka Violet Cushion x Local } \\
\text { Violet }\end{array}$ & - & - & 33.59 & 91.50 & 0.25 & 0.27 \\
\hline Arka Violet Cushion x Local Pink & & & 34.33 & 55.58 & 0.16 & 0.29 \\
\hline Arka Kamini & 161.30 & 0.33 & - & - & - & 0.21 \\
\hline Arka Poornima & 194.80 & 0.43 & - & - & - & 0.22 \\
\hline Arka Aadya & 94.60 & 0.20 & - & - & - & 0.21 \\
\hline Arka Archana & 175.85 & 0.45 & - & - & - & 0.26 \\
\hline Arka Violet Cushion & 9.95 & 0.029 & - & - & - & 0.26 \\
\hline Arka Shashank & 29.95 & 0.098 & - & - & - & 0.32 \\
\hline Local Violet & 171.45 & 0.39 & - & - & - & 0.21 \\
\hline Local Pink & 203.75 & 0.54 & - & - & - & 0.25 \\
\hline Mean & 130.21 & 0.31 & 35.47 & 64.16 & 0.17 & 0.26 \\
\hline Range & $9.95-203.75$ & $0.029-0.54$ & $31.33-39.83$ & $31.5-111.17$ & $0.092-0.29$ & $0.21-0.32$ \\
\hline SEm \pm & 11.42 & 0.027 & 1.16 & 4.22 & 0.013 & 0.03 \\
\hline C.D. at $5 \%$ & 38.84 & 0.093 & 3.55 & 12.91 & 0.041 & 0.09 \\
\hline
\end{tabular}


Table.2 Estimates of heterosis (\%) over mid parent (MP), better parent (BP) and commercial check (CC) cv. Arka Kamini in $15 \mathrm{~F}_{1}$ hybrids for 100 seeds weight $(\mathrm{g})$

\begin{tabular}{|c|c|c|c|c|c|c|c|}
\hline Cross combinations & Hybrids & Female parent & Pollen parent & $\begin{array}{l}\text { Average/ mid } \\
\text { parent }\end{array}$ & MP & BP & $\mathrm{CC}$ \\
\hline Arka Kamini x Arka Shashank & 0.273 & 0.211 & 0.322 & 0.267 & $1.13 *$ & -16.24 & $29.38^{*}$ \\
\hline Arka Kamini x Local Violet & 0.252 & 0.211 & 0.215 & 0.213 & $17.91 *$ & $17.02 *$ & $19.43^{*}$ \\
\hline Arka Kamini x Local Pink & 0.245 & 0.211 & 0.25 & 0.231 & $5.86^{*}$ & -2.30 & $16.11 *$ \\
\hline Arka Poornima x Arka Shashank & 0.266 & 0.219 & 0.322 & 0.271 & -2.40 & -17.95 & $26.07 *$ \\
\hline Arka Poornima x Local Violet & 0.236 & 0.219 & 0.215 & 0.217 & $9.97 *$ & $8.78^{*}$ & $11.85^{*}$ \\
\hline Arka Poornima x Local Pink & 0.258 & 0.219 & 0.25 & 0.235 & $10.02 *$ & $3.30^{*}$ & $22.27 *$ \\
\hline Arka Aadya x Arka Shashank & 0.271 & 0.21 & 0.322 & 0.266 & $0.52 *$ & -17.02 & $28.44 *$ \\
\hline Arka Aadya x Local Violet & 0.253 & 0.21 & 0.215 & 0.213 & $17.93^{*}$ & $16.55^{*}$ & $19.91 *$ \\
\hline Arka Aadya x Local Pink & 0.261 & 0.21 & 0.25 & 0.230 & $13.45^{*}$ & $4.30^{*}$ & $23.70 *$ \\
\hline Arka Archana x Arka Shashank & 0.303 & 0.257 & 0.322 & 0.290 & $4.28 *$ & -6.29 & $43.60 *$ \\
\hline Arka Archana x Local Violet & 0.288 & 0.257 & 0.215 & 0.236 & $23.57^{*}$ & $13.45^{*}$ & $36.49 *$ \\
\hline Arka Archana x Local Pink & 0.281 & 0.257 & 0.25 & 0.254 & $8.84 *$ & $7.41^{*}$ & $33.18 *$ \\
\hline Arka Violet Cushion x Arka Shashank & 0.289 & 0.255 & 0.322 & 0.289 & $0.74 *$ & $\begin{array}{c}-9.71 \\
\end{array}$ & $36.97 *$ \\
\hline Arka Violet Cushion x Local Violet & 0.271 & 0.255 & 0.215 & 0.235 & $15.66^{*}$ & $6.47 *$ & $28.44 *$ \\
\hline Arka Violet Cushion x Local Pink & 0.291 & 0.255 & 0.25 & 0.253 & $14.91 *$ & $13.73^{*}$ & $37.91 *$ \\
\hline
\end{tabular}

$*=$ significant at $5 \%$ 
Standard heterosis over commercial check Arka Kamini was ranged from 11.85 (Arka Poornima x Local Violet) to 43.60 (Arka Archan x Arka Shashank). This shows that the hybrid seeds were bolder than the parents, showing heterosis.

Out of 15 crosses, 14 crosses recorded positive significant heterosis over mid parent; 9 crosses displayed positive significant heterosis over better parent, while, all the crosses observed positive significant heterosis over commercial check cv. Arka Kamini.

In conclusion, a study was carried out to ascertain crossability among $15 \mathrm{~F}_{1}$ hybrids and 8 parents of China aster by recording seed setting related parameters such as days taken for hybrid seed maturity, total number of seeds/cross, seed weight/cross and 100 seed weight. The genotypes and their hybrids showed significant variation in seed setting. The cross Arka Poornima x Local Pink recorded highest total number of seeds per cross (111.17) and weight of seeds per cross $(0.29 \mathrm{~g})$. The average 100 seeds weight in $F_{1}$ hybrids $(0.269 \mathrm{~g})$ was higher than that of parents $(0.242 \mathrm{~g})$. All the $15 \mathrm{~F}_{1}$ hybrids exhibited heterosis over commercial check cv. Arka Kamini for 100 seeds weight.

\section{References}

Bailey, L.H. 1942. The standard cyclopaedia of Horticulture. Macmillan, New York. 3: 419-422.

Emsweller, S.L. 1948. Breeding of ornamental plants. Proceedings of the American Society for Horticultural Science. 51: 565-574.

Fleming, W.M. 1937. In: U.S.D.A Year book of agriculture, U.S. Department of Agriculture, pp. 985.

Janakiram T. 1997. Production technology of China aster. In: Progressive Floriculture. pp. 137-142.
Khangjarakpam, G., Kumar, R., Seetharamu, G. K., Rao, T. M., Dhananjaya, M. V., Venugopalan, R. and Padmini, K. 2014. Seed setting studies in China aster [Callistephus chinensis (L.) Nees]. Progressive Agriculture. 14(1): 189191.

Kong, H. 2000. A study on karyotype of Callistephus chinensis Nees. Guihaia. 20(4): 339-340.

Munikrishnappa, P. M. 2011. Study on the standardization of production technology in China aster under transitional tract of North Karnataka. Ph.D. Thesis. University of Agricultural Sciences, Dharwad.

Navalinskien, M., Samuitien, M. and Jomantiene, R. 2005. Molecular detection and characterisation of phytoplasma infecting Callistephus chinensis plants in Lithuania. Phytopathology. 35: 109-112.

North, C. 1979. Plant breeding and genetics in horticulture. Mac Millan press Ltd. London, pp. 107.

Novotna, I. 1989. The floral biology of China aster (Callistephus chinensis Nees) from the genetic and breeding aspects. Sbornik UVTIZ, Zahradnictvi. 16(1): 55-64.

Padmini, K., Janakiram, T. and Naik, L. B. 2012. Floral biology studies in China aster (Callistephus chinensis L.) Nees powder puff type cv. Poornima. Journal of Ornamental Horticulture. 15(3\&4): 147-153.

Phetpradap, L. 1992. Seed production in China aster (Callistephus chinensis (L.) Nees.). PhD thesis, Massey University, Palmerston North, New Zealand.

Sajabapu, B. S. 2015. Seed set studies in China aster (Callistephus chinensis (L.) Nees). Department of Horticulture, College of Agriculture, Mahatma Phule Krishi Vidyapeeth, Rahuri. pp. 413-722. Selvakumari, A., Sivasubramaniam, K. A., 
Kumar V. and Sujatha, K. 2006. Studies on seed development and maturation in China aster (Callistephus chinensis L.) cv. Poornima. Plant Archives. 6(2): 663-665.

Sheela, V. L. 2008. Flowers for Trade. New India Publishing agency. Pitam pura. New Delhi. pp.117.

Strube, H. 1965. New ertenntnisse and erfahrungen in der astern suchtung I and
II (New knowledge and results in aster breeding I and II). Dtsche gertenb. 12: 134-136.

Watts, L. 1980. Flower and vegetable plant breeding. Grower Books, London, pp. 182.

Yadav, L.P. 1983. Ph.D. Thesis. Bidhan Chandra Krishi Viswavidyalaya. Calcutta, India.

\section{How to cite this article:}

Pratiksha Kumari, Rajiv Kumar, T. Manjunatha Rao, T. Usha Bharathi, M.V. Dhananjaya and Bhargav, V. 2018. Crossability Studies in China Aster [Callistephus chinensis (L.) Nees]. Int.J.Curr.Microbiol.App.Sci. 7(02): 2169-2175. doi: https://doi.org/10.20546/ijcmas.2018.702.260 